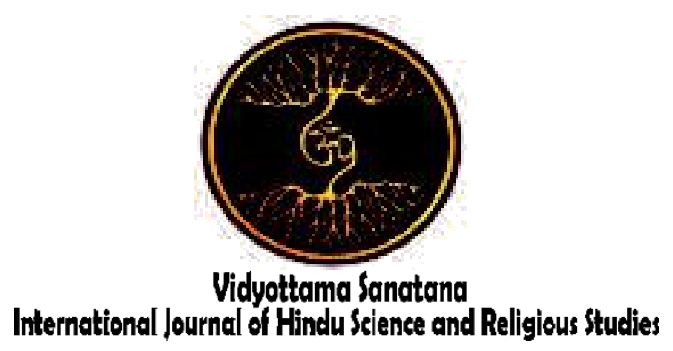

Vol. 4 No. 1 May 2020

\title{
MULTICULTURALISM IN HINDU RELIGIOUS EDUCATION PERSPECTIVE
}

\author{
By: \\ Ida Bagus Subrahmaniam Saitya ${ }^{1}$, I Komang Suastika Arimbawa ${ }^{2}$, Acyutananda \\ Wayan Gaduh $^{3}$, Putu Emy Suryanti ${ }^{4}$, Ni Putu Ersa Rahayu ${ }^{5}$ \\ ${ }^{1234}$ Universitas Hindu Negeri I Gusti Bagus Sugriwa Denpasar \\ ${ }^{5}$ STAHN Mpu Kuturan Singaraja \\ E-mail : ${ }^{1}$ subrahmaniam@ihdn.ac.id, ${ }^{2}$ suastikaarimbawa@ihdn.ac.id,

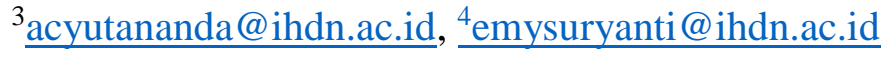

Received: May 02, 2020

Accepted: May 21, 2020

Published: May 30, 2020

\begin{abstract}
Indonesia, like other developing countries, has social problems that are not simple. The economic crisis followed by various other crises made people aware of the importance of social capital. Social capital is the collective energy of the community in the form of togetherness, solidarity, cooperation, tolerance, trust, and responsibility of every society members in playing their duties and obligations. The development of dynamic society and social problems that continue to develop these days, require attention and sensitivity from all nation elements, not only from experts and observers of social problems but also the education world, especially concerning religious education which has a very strategic role as a vehicle and "agent of change" for the society. The pluralistic condition of Indonesia both in terms of ethnicity, race, religion, and social status makes an extraordinary contribution to the development and dynamics in society. Therefore, it is considered very important to provide a portion of religious education in a multicultural perspective in the Indonesian education system, both through substance and learning models. This is considered important to provide a briefing and foster the development of insight and personality, also train students' sensitivity in facing the social symptoms and problems that occur in society.
\end{abstract}

Keywords: Hindu Religious Education and Multiculturalism 


\section{INTRODUCTION}

The development of national development in the industrialization era in Indonesia has led to the emergence of side effects in society. Conglomeration and capitalization have grown the seeds of problems that exist in society such as inequality between the rich and the poor, the problem of capital owners and workers, poverty, the struggle for natural resources, and so on. Besides, the condition of pluralistic Indonesia society in terms of ethnicity, religion, race, and geography contributes to social problems such as social inequality, conflicts between groups, tribes, and so on.

Awareness about multiculturalism has emerged since the Republic of Indonesia was formed and used by the founders of the Indonesian Nation to "design the Indonesian cultures". However, the concept of multiculturalism is a new and foreign concept for Indonesia these days (Suparlan (2002). Due to the awareness of multiculturalism concepts formed by the founder of this nation did not materialize during the New Order. This awareness is buried in the name of national unity and stability, which then emerged mono-culturalism and became the main pressure. Finally, it imposes a pattern of "uniformity" characteristics on various aspects, social systems, politics, and culture, hence until now the insight of Indonesian multiculturalism is still low.

Cultural differences, religion, political aspirations, interests, vision and mission, beliefs, and traditions are conduction in interpersonal relationships which sometimes become behavioral differences in understanding something. Therefore, it can be said that various ethnic confusion that spread in many places in Indonesia, is part of the multi-dimensional crisis faced by Indonesia since mid-1997 at the end of the New Order regime as a result of low awareness and multiculturalism insight.

The failure of this education system lies in the failure of the humanities education system, which includes religious education. The humanities area is often seen as a complement in the Indonesian education system because it is considered no guarantee the future of students materially.

In addition, the helplessness of the religious education system is due to the emphasis on religious education all this time in the process of transferring religious knowledge to students, not the process of transforming religious noble values to students to guide them become human beings with strong personalities and noble character; it must be aware that religious education is laden with normative and historical empirical content. Educational problems are quite complex problems because they are related to quantity problems, quality problems, relevance problems and effectiveness problems.

Quantity problems arise as a result of the relationship between the growth of the education system and population growth, the quality problem is a matter of how to improve the ability of human resources, the problem of the quality of education is a serious problem in the survival of the nation and state, the handling of quality aspects is closely related to the handling of aspects quantity, therefore there needs to be a balance between the two. The issue of relevance arises from the relationship between the education system and national development, and people's expectations about increasing educational output. The issue of effectiveness is a problem of the ability to implement education while the problem of efficiency is essentially also a problem of education management (Sudarsana, 2018).

Therefore, it is very interesting to review, examine, examines the paradigms of the concepts and thoughts of religious education offered by the curriculum, syllabus, literature, and teachers in the field in the plurality era. If such efforts are linked to searching for some sources or roots of conflict and social unrest in a plural society. This is the importance of imaging Religious Education (Hindu) should be set in the perspective of multicultural education, when ignoring it, it same as letting fire in the husk; because 1) in every religion cannot leave emotions at all, whereas emotions are the 
embryo of aggressiveness that is easy to turn towards violence; 2) religious activities can prevent violence if it functions properly as a damper. However, religious activities can be transformed into a powerful thrust and trigger violence, if it creates feelings of frustration and dissatisfaction for its adherents; Nonaggressive religious societies are usually conditioned by the style and models of religious education offered by religious leaders, society or religious groups (Abdullah, 2005).

Hindu religious education in the multiculturalism perspective is a movement of religious education renewal and innovation to instill an awareness of the importance of living together in diversity, with a spirit of equality, mutual trust and understanding, and respect for the similarities, differences, and uniqueness of religions. It is intertwined in relations and interdependence in situations of hearing and accepting different religions' perspectives in an issue and another with an open mind, to find the best way to overcome conflicts between religions and create peace through means of forgiveness and nonviolence.

\section{METHODS}

This study used a qualitative approach with a library research method (literature study), in which Hindu religious education as a moral-spiritual value base must be able to be a solution to the emergence of the globalization effects. The concept of multicultural-religious education was a combination of multicultural education concepts that emphasize respect attitude towards diversity with the concept of religious education, which emphasizes submissive attitudes towards God's commands. Data collection was carried out by studying relevant libraries that rise humanist and religious humans. The data analysis technique used was content analysis. Data analysis can be done through data display stages, data reduction, data verification, and conclusions.

\section{RESULTS AND DISCUSSIONS}

\section{Hindu Religious Education}

The concept of Hindu religious education is in line with the definition of education in general. Education is an effort to develop Indonesian people who are cultured, devoted to God Almighty, have a noble character, think, say, and behave must be rooted in the truth. The definition of Hindu religious education in the The Decision of Seminar in Unity of Interpretation of Hinduism I - IV in Denpasar, can be seen as follows:

Hindu religious education outside of school is an effort to foster the development of society soul with the teachings of Hinduism itself as the subject matter, while Hindu religious education in school is an effort to foster the development of the body and soul of students in accordance with Hindu Religious Education (Proyek Daerah Tingkat I Bali, 1980: 1-2).

If related to the definition of education in general with the definition of Hindu religious education, then basically it must be examined the function of Hinduism itself in relation to the stated educational objectives. In this case, Hindu religious education is encouragement in achieving educational objectives, especially in the development of human personality.

Based on the description above, it can be said that Hindu religious education is an effort carried out by Hindu widely, planned, directed, and continue to achieve growth, development of personality, and attitudes of noble character and devotion to God Almighty (Ida Sang Hyang Widhi Wasa).

\section{Multiculturalism}

The multiculturalism discourse for the context in Indonesia found its momentum when an authoritarian-militaristic national system collapsed along with the fall of the Soeharto regime. At that time, the state of the country became chaotic with various conflicts between ethnicities, which caused fear in society. These conditions make various parties increasingly questioned again the national system, what kind of systems that 
suitable for a changing Indonesia, as well as what systems can make Indonesia society can live peacefully by minimizing the potential for conflict.

According to Suparlan (2002), multiculturalism is a concept that able to answer the challenges of time development on the grounds that multiculturalism is an ideology that glorifies cultural differences, or a belief that recognizes and encourages the realization of cultural pluralism as a form of the community life. Multiculturalism will be a binder and a bridge that accommodates differences including differences in ethnicity in a multicultural society. These differences can be contained in public places, workplaces and markets, and national systems in terms of political, legal, economic, and social equality.

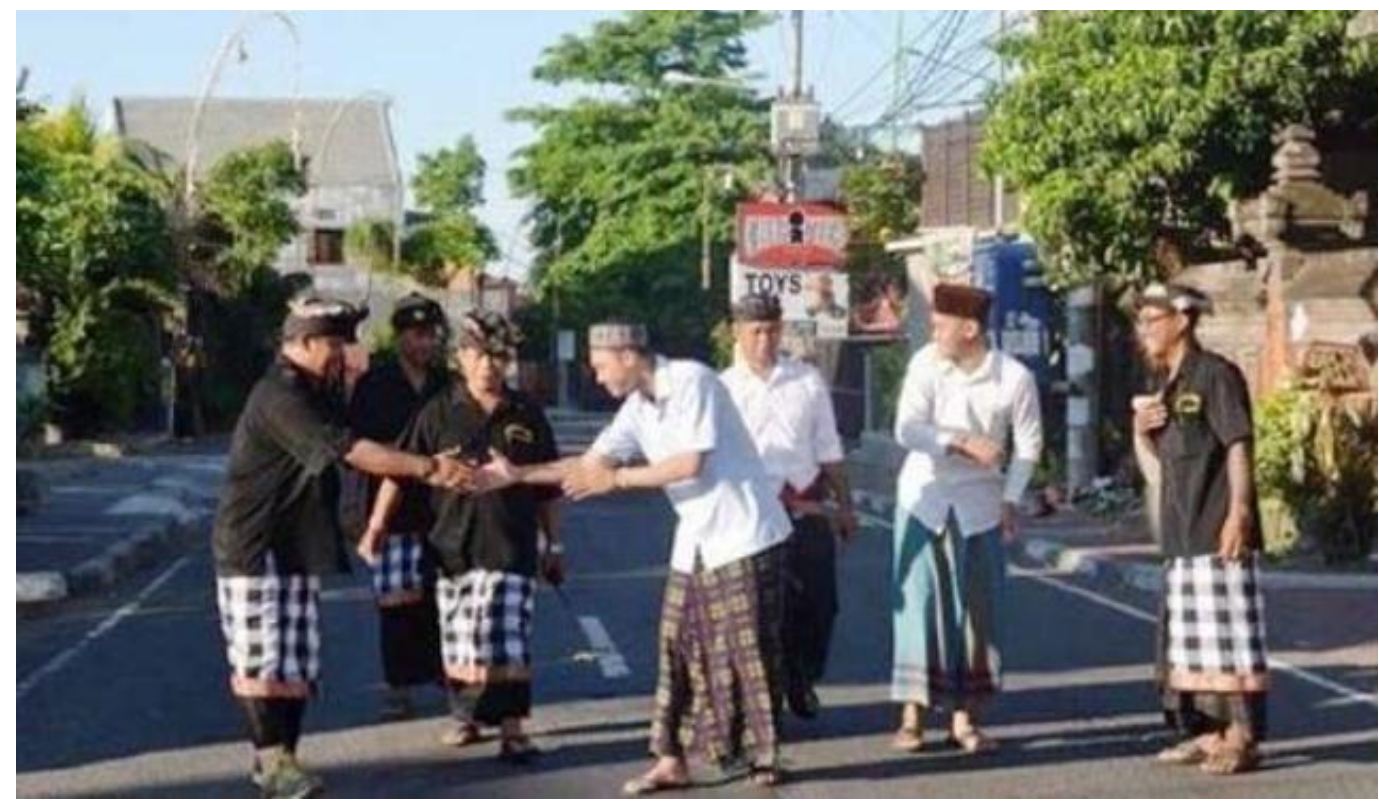

Figure 1 Reflecting on Interfaith Tolerance in Bali

(Source : https://baliexpress.jawapos.com/read/2019/03/11/124308/berkaca-dari-toleransilintas-agama-di-bali)

According to Fay, 1996; Rex, 1985 movement between humans and culture (Suparlan, 2002), multiculturalism explains various issues that support the ideology, politics, democracy, justice, law enforcement, employment and business opportunities, human rights, community cultural rights and minority groups, ethical and moral principles, levels and the quality of productivity and various other relevant concepts. This concept is in line as stated by Blum, (Atmadja, 2003), that multiculturalism includes an understanding, appreciation, and evaluation of a person's culture and respect, also curiosity about the ethnic cultures of others. It means that it includes an assessment of other people's cultures, not in the sense of agreeing to all aspects of those cultures, however trying to see how certain cultures can express the value for their members.

Multiculturalism is a global phenomenon, the result of accelerated which both coexistence peacefully. Requirements for the presence or absence of multiculturalism in the culture and society (structure) of a country or region, must be seen first from the presence or absence of peace between people and different cultures (Wijaya, 2005). According to Rahmat (2008), multiculturalism reflects a balance between an understanding of equality and cultural differences that encourage individuals to maintain and expand their own cultural and cultural insights. Furthermore, according to Jose A. Cardinal (1975), the importance of multicultural education is based on five considerations, namely:

a. Incompatibility (the inability to live in harmony)

b. Other languages acquisition (other language demands) 
c. Cultural pluralism (cultural diversity)

d. Development of positive self-image (development of a positive selfimage), and

e. Equality of educational opportunity (equality in getting educational opportunities)

On the other hand, Donna M. Gollnick (1983) states that the importance of multicultural education is motivated by several assumptions:

a. Each culture can interact with other different cultures and even can contribute to each other. b. Cultural diversity and interactions are at the core of today's society.

c. Social justice and equal opportunities for all people are the rights of citizens.

d. The power distribution can be shared equally among all ethnic groups.

e. The education system provides a critical function to attitude and value framework needs for the survival of democratic societies; and

f. Teachers and education practitioners can assume a leadership role in creating an environment that supports multicultural education.

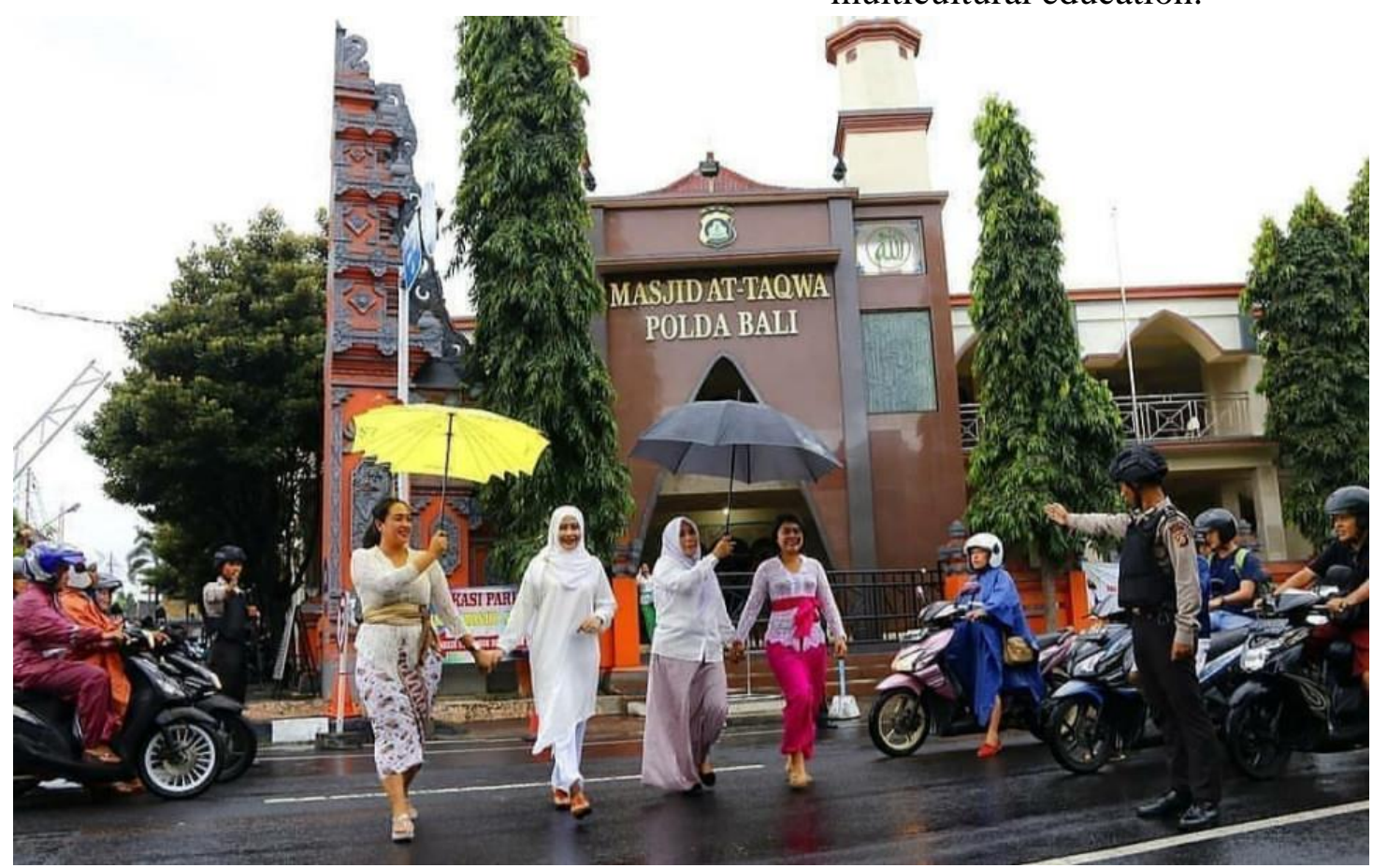

Figure 24 Portrait of Religious Tolerance in Bali Soothing

(Source : https://akurat.co/ramadan/id-619172-read-4-potret-toleransi-beragama-di-bali-yangmenyejukkan-hati)

Based on the perspectives and concepts above, multiculturalism has the relevance of meaning and proper function. Thus, the concept of multiculturalism becomes important to be developed and internalized in the process of transforming the values of society and diversity. It because the basic principles of multiculturalism recognize and respect the diversity of community groups such as ethnicity, race, culture, gender, social strata, religion, differences in interests, groups differences, beliefs and traditions which will be helpful for the realization of changing the conducive social behaviors formats and it promising amid of a pluralistic nation and community life.

\section{Hindu Perspectives on Multiculturalism}

Hindu religious education in Indonesia is an integral part of national education. The arrangement and regulation of Hindu religious education are inherent with national education, which means that when there is a new discourse related to national education 
policy, indirectly will have implications for Hindu religious education. As already stated above, the effort to build a multicultural perspective in the society by actively involving the education community as an initial initiative in making togetherness amidst religious plurality, the culture that becomes the great discourse of the nation elements.

Hinduism contains many teachings relating to multiculturalism, such as the teachings of tat twam asi, karma phala, and ahimsa.

a. Tat twam asi is unlimited social teaching. In Sanskrit, the word "tat" comes from the syllable "tad" which means "that" or "he". The word "tvam" comes from the syllable "yusmad" which means "you" and "asi" comes from the word "as (a)" which means "is". Therefore, simply that the word "Tat Twam Asi" can be meant "you are that" or "that is you". In Katha Upanisad, it is stated as follows:

\section{nityo nityanam cetanas cetananam} eko bahunam yo vidadhati kaman tam pitha-gam ye 'nupasyanti dhiras tesam santih sasvati netaresam Translation:

Among the eternal and conscious personalities, there is one personality that provides for other personalities' needs. A wise person who worships this personality, who resides in His spiritual nature will be able to achieve true peace while others, who do not worship Him, will not achieve peace.
The family and kinship system is an inherent characteristic in Indonesian cultures. No exception to the Hindu community in Bali. The system becomes customary law for the creation of relations between humans and humans. Human relations of Hinduism in Bali are contained in the philosophy of "Tat Twam Asi" as a legal basis. Literally, Tat means he, Twam means you, and Asi means is. Overall means "he is you". I am is you and all beings are the same. It means that helping others means helping yourself. And hurting others means hurting yourself. Simply stated the sentence states that you and it are the same, it makes no difference, it means that we are all the same. Because we are all the same, what we do to others is also what we do to ourselves. Insulting, hurting and bringing down others is the same as insulting and hurting yourself. Helping and respecting others is the same as respecting oneself (Wariati, 2016). This basic principle of Tat Twam Asi in Balinese customary life is given an understanding of several principles. It can be seen as follows.

a. The principle of joy and sorrow means that joy and sorrow are felt together.

b. The principle of paras paros means that other people are part of oneself and oneself is part of others.

c. The principle of salunglung sabayantaka means that good or bad, lives and death are shared.

d. The principle of asah, asih, asuh means that we love each other, given to each other and correct, and help each other. 


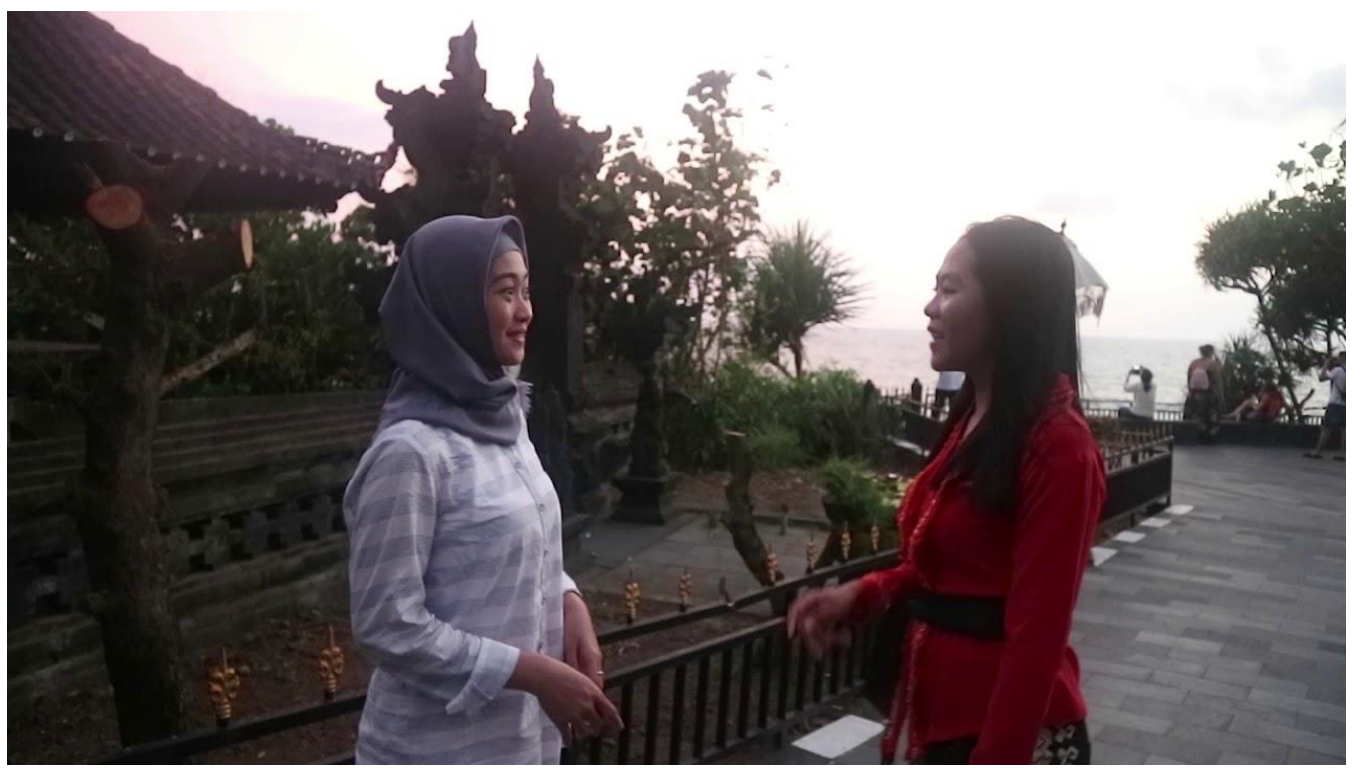

Figure 3 Multiculturalism in Bali

(Source : https://www.youtube.com/watch?v=DAuMYeCL5VU)

Human life is not only related to God, but also related to fellow humans and the environment. Humans are social creatures who cannot live alone, live in groups, and cannot be separated from the participation of other humans in their lives. Humans must have the same sense of unity to be able to interpret the way to respect someone contained in the teachings of Hinduism, namely the teachings of Tat Twam Asi (Kusuma, 2018).

\section{b. Karmaphala}

Karma comes from Sanskrit, which means acts (deed) and Phala which means result. Therefore, Karmaphala is the result of deeds. It also called the law of karma or the law of action. The law of Karmaphala is in line with the law of cause and effect, which every cause has an effect. Likewise, with the law of karma, every karma has Phala. Therefore, the law of karma is often called the law of Karmaphala. Doctrine karmaphala very important role to provide guidance for Hindus to do better, in order to get the reward or better results (Widnyana, 2017).

The law of Karmaphala is the law of cause and effect, the law of action, the law of effort and results, or fate. This law applies to the universe, animals, plants, and humans. If the law is addressed to humans, it is called the law of karma and if to the universe, it is called the law of Rta. This law governs the survival, movement, and rotation of the universe. In Kekawin Ramayana Sargah 1 stanza number 4: "Lust and others (Sad Ripu) are the closest enemies, in the heart, not far from the body. It is not in Him, only courage, wisdom, and political knowledge that He has".

c. Ahimsa

Ahimsa is also the foundation of harmony in religious life. Ahimsa means non-violence. Etymologically, ahimsa means not killing and hurting other living things. "Ahimsa parama dharmah" is a simple sentence but containing deep meaning. Not hurting is the ultimate virtue or the highest dharma. Every struggle for the defense of truth should not be done by vandalism, because of the destructive nature, looting, forcing, threatening, terrorizing, burning, etc. It is very contrary to karma and ahimsa, including hurting other people's heart with bad intentions, or by harsh words and swearing. The virtue of ahimsa is because of the high values as 
expressed in other sentences as follows: Ahimsaayah paro dharmah, ahimsaa laksano dharmah, ahimsaa parama tapa, ahimsaa parama satya, it means that Ahimsa is the highest virtue, dharma deed, highest selfcontrol, and truth. Ahimsa is a struggle without violence, including without opposing natural laws. If it violates the laws of nature, it will invite strong reactions. They must learn to maintain and protect their own environment, hence to create a harmonious life in harmony with their environment. Therefore, ahimsa implies that not do violence in the form of not killing any living thing, ahimsa is also intended not to do violence hence it does not hurt someone's heart. Contrary to ahimsa karma, adharma is the act of killing and it is contrary to religion.

\section{CONCLUSION}

Religious education and teaching at this time still nuances of the classical-scholastic era which is emphasizing salvation based on the goodness relationship between an individual with his God, but does not put good emphasis between the individual and other individuals. The presence of religion is understood as a blessing for a person or individual, or at least for a group of a particular religion.

A wrong understanding of the moral message of religion in universal will lead to the emergence of some attitudes, namely the truth claims, exclusiveness, excessive fanaticism, and apology. Such an attitude, when an individual is dealing with other individuals outside the group, there will be friction and even conflict. Whereas socially and culturally, Indonesia is a multicultural, multi-ethnic, and multi-religious nation. Therefore, this is the importance of developed multiculturalism-oriented education.

Integrated Islamic Religious Education can be developed within the Multiculturalism Education framework both regarding the scope of material in the curriculum, teaching methods, and the paradigm of concept preparation and implementation. Thus, it is expected that religion will become conditioning for our social life and create a peaceful atmosphere in the plural society life.

\section{REFERENCES}

Abdullah, M. A. (2005). Pendidikan agama era multikultural-multireligius. Jakarta: Pusat Studi Agama dan Peradaban Muhammadiyah.

Atmadja (2003). Multikulturalisme dalam Perspektif Filsafat Hindu, Makalah di Sajikan dalam Seminar Damai Dalam Perbedaan, Singaraja, 5 Maret 2003.

Cardinas, J. A. (1975). Multicultural Education: A Generation of Advocacy. America: Simon \& Schuster Custom Publishing.

Gollnick, D. M. (1983). Multicultural Education in a Pluralistik Society. London: The CV Mosby Company.

Kusuma, I. G. L. A. W. (2018). Implementasi Ajaran Tat Twam Asi Terhadap Mahasiswa Penyandang Tunanetra Di IHDN Denpasar. Jurnal Penelitian Agama Hindu, 2(2), 587-591.

Rahmat, P. S. (2008). Wacana Pendidikan Multikultural di Indonesia (Sebuah Kajian terhadap MasalahMasalah Sosial yang Terjadi Dewasa ini).

Sudarsana, I. K. (2018). Optimalisasi Penggunaan Teknologi Dalam Implementasi Kurikulum Di Sekolah (Persepektif Teori Konstruktivisme). Cetta: Jurnal Ilmu Pendidikan, 1(1), 8-15.

Suparlan, P, (2002), Menuju Masyarakat Indonesia Yang Multikultural, Makalah, Disajikan pada Simposium Internasional Jurnal Antropologi Indonesia ke-3, Membangun Kembali "Indonesia yang Bhinneka Tunggal Ika", Menuju Masyarakat Multikultural, Universitas Udayana, Denpasar, Bali, 16-19 Juli 2002 
Wariati, N. L. G. (2016). Meningkatkan Mutu ASN IHDN Denpasar dengan Pelayanan Publik Berbasis Tat Twam Asi. Jurnal Penjaminan Mutu, 2(2), 74-83.
Widnyana, I. G. S. (2017). Persepsi Umat Hindu Terhadap Ajaran Karmaphala Dalam Teks Agastya Parwa Di Desa Songan Kintamani Bangli. Jurnal Penelitian Agama Hindu, 1(2), 448453. 